\title{
ЗДОБУТКИ ТА ПЕРСПЕКТИВИ РОЗВИТКУ СТАЦІОНАРНОЇ МЕДИЧНОЇ ДОПОМОГИ В УКРАЇНІ
}

\author{
Національна медична академія післядипломної освіти імені П.Л. Шупика, м. Київ, Україна
}

\begin{abstract}
Мета: аналіз показників діяльності стаціонарів України за 2005-2014 рр. з визначенням перспектив подальших напрямів ресрормування стаціонарної медичної допомоги.

Матеріали і методи. Використані вітчизняні наукові та статистично-довідкові матеріали за темою; застосовувалися наступні методи: бібліосемантичний, медико-статистичний, системного підходу і системного аналізу.

Результати. Незважаючи на упорядкування мережі лікарень і розвиток закладів сімейної медицини, залишаються високими показники забезпеченості населення стаціонарними ліжками (71,9 на 10 тис. нас., у країнах $€ C-55,0)$, тривалості перебування хворого на ліжку (11,6 дня, середньоєвропейський показник - 9,2 дня) при скороченні середнього числа днів роботи ліжка у міських (з 339,84 до 331,0), центральних районних (3 333,76 до 320,8), дільничних ( 341,2 до 329,9), районних лікарнях (з 336,9 до 327,8) та ліжкового фронду денних стаціонарів (3 4659 од. до 1924 од.).

Висновки. Існують резерви поліпшення використання ліжкового фонду щодо обсягу ліжкового фронду, термінів перебування на ліжку та подальшого розвитку стаціонарозамінних фрорм медичної допомоги.
\end{abstract}

КЛЮЧОВІ СЛОВА: ліжковий фонд, стаціонарна медична допомога, раціональне використання ресурсів.

Реорормування галузі охорони здоров'я України спрямовано на найбільш повне задоволення потреб громадян у якісній медичній допомозі за умови раціонального використання наявних ресурсів. Зокрема реформування мережі лікарень, утримання яких $€$ найбільш затратним для охорони здоров'я, визначено одним з пріоритетних напрямів Національної стратегії побудови нової системи охорони здоров'я на період 2015-2025 років [2]. Незважаючи на те, що в Україні вже відбулося скорочення ліжкового фронду, за даними наукових досліджень, існуюча мережа закладів охорони здоров'я не задовольняє в повному обсязі потребу населення в доступній, високоякісній та ефективній медичній допомозі та працює за умов розпорошеності ресурсів галузі $[1 ; 4 ; 5]$. Це вимагає подальшого аналізу здобутків діяльності стаціонарної мережі та визначення перспектив її розвитку на шляху до європейської інтеграції.

Мета дослідження: провести системний аналіз показників діяльності стаціонарів України за 2005-2014 рр. і визначити перспективи подальших напрямів реформування стаціонарної медичної допомоги.

Матеріали і методи. Використані вітчизняні наукові та статистично-довідкові матеріали за темою. Застосовувалися наступні методи: бібліосемантичний; системного підходу і системного аналізу, медико-статистичний.

Результати дослідження та їх обговорення. Аналіз кількісних і якісних змін, які відбувались у системі охорони здоров'я у 2005-2014 рр., за даними Центру медичної статистики МОЗ України та опублікованих результатів наукових досліджень

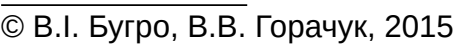

опублікованих результатів наукових досліджень [6-11], дозволив стверджувати, що вони торкалися визначених на нормативному рівні пріоритетних напрямів і охоплювали упорядкування та реорганізацію мережі закладів охорони здоров'я первинного і вторинного рівнів медичної допомоги, оптимізацію їх структури. Зокрема відбулася зміна чисельності закладів, які надають амбулаторнополіклінічну і стаціонарну медичну допомогу, з поступовим збільшенням кількості закладів загальної практики/сімейної медицини (ЗП/СМ) (табл. 1). Число останніх зросло з 4404 од. у 2009 р. до 5656 од. у 2014 р. За аналітичними даними фрахівців Інституту стратегічних досліджень МОЗ України, загалом ЗП/СМ охоплено 76,9\% населення в Україні. Цей показник знизився у 2014 р. порівняно з 2013 р. на 14,3\% у зв'язку з відсутністю моніторингових даних 3 тимчасово окупованих територій Донецької і Луганської областей.

При збільшенні числа закладів ЗП/СМ за десять років (2005-2014 рр.) значно скоротилася мережа лікарняних закладів системи МОЗ України - із 2636 до 1504 од. (на 75,3\%). Число лікарень у перерахунку на 100 тис. нас. зменшилось з 5,6 у 2005 р. до 4,48 у 2012 р. (у країнах Європейського союзу даний показник становив 3,11). Відповідно зменшувалось число стаціонарних ліжок в Україні, а показник забезпеченості ними населення скоротився 3 87,2 до 71,9 на 10 тис. нас. (у країнах $Є С-55,0$ ).

Упорядкування стаціонарної медичної допомоги супроводжувалось розвитком її альтернативних форм - денних стаціонарів та стаціонарів вдома. Кількість закладів, що використовували дані фоорми стаціонарної допомоги, спочатку зростала-від- 
Таблиця 1. Динаміка змін мережі закладів охорони здоров'я системи мО3 України (2005-2014 рр.)*

\begin{tabular}{|c|c|c|c|c|c|}
\hline \multirow{2}{*}{ Показник } & \multicolumn{5}{|c|}{ Рік } \\
\hline & 2005 & 2006 & 2007 & 2008 & 2009 \\
\hline $\begin{array}{l}\text { Число закладів, які надають амбулаторно- } \\
\text { поліклінічну допомогу }\end{array}$ & 6692 & 6792 & 6842 & 6842 & 6880 \\
\hline з них закладів, які мають денні стаціонари & 4659 & 4800 & 4910 & 5047 & 5111 \\
\hline з них закладів, які мають стаціонари вдома & 4214 & 4420 & 4629 & 4586 & 4609 \\
\hline Число закладів ЗП/СМ & & & & & 4404 \\
\hline Число лікарняних закладів & 2636 & 2622 & 2574 & 2537 & 2487 \\
\hline на 100 тис. нас. & 5,6 & & & 5,63 & \\
\hline Число лікарняних ліжок (усього) & 407464 & 406870 & 404212 & 402955 & 397167 \\
\hline на 10 тис. нас. & 87,2 & 87,6 & 87,51 & 87,67 & 86,75 \\
\hline Число ліжок у денних стаціонарах (усього) & 61933 & 63514 & 65160 & 66105 & 67736 \\
\hline на 10 тис. нас. & 13,2 & 13,7 & 14,1 & 14,4 & 14,8 \\
\hline \multirow[b]{2}{*}{ Показник } & \multicolumn{5}{|c|}{ Pik } \\
\hline & 2010 & 2011 & 2012 & 2013 & 2014 \\
\hline $\begin{array}{l}\text { Число закладів, які надають амбулаторно- } \\
\text { поліклінічну допомогу }\end{array}$ & 6869 & 6105 & 4681 & 3726 & 2947 \\
\hline з них закладів, які мають денні стаціонари & 5165 & 4508 & 4295 & 2446 & 1924 \\
\hline з них закладів, які мають стаціонари вдома & 4687 & 4236 & 3885 & 2263 & 1602 \\
\hline Число закладів ЗП/СМ & 4581 & 5373 & 6095 & 6457 & 5656 \\
\hline Число лікарняних закладів & 2442 & 2156 & 2042 & 1819 & 1504 \\
\hline на 100 тис. нас. & 4,1 & & 4,48 & & \\
\hline Число лікарняних ліжок (усього) & 394374 & 377291 & 369657 & 364241 & 307246 \\
\hline на 10 тис. населення & 86,49 & 83,01 & 81,5 & 80,5 & 71,9 \\
\hline Число ліжок у денних стаціонарах (усього) & 69045 & 72299 & 72379 & 71944 & 61599 \\
\hline на 10 тис. населення & 15,1 & 15,9 & 16,0 & 15,9 & 14,4 \\
\hline
\end{tabular}

Примітка: за даними Центру медичної статистики МОЗ України.

повідно з 4659 од. у 2005 р. до 5165 од. у 2010 р. та з 4214 од. у 2005 р. до 4687 у 2010 р., але надалі значно зменшилась - відповідно до 1924 од. та 1602 од. при одночасному зростанні кількості пролікованих у них хворих - відповідно з 477,7 у 2005 р. до 601,0 у 2014 р. та 3402,7 у 2005 р. до 514,1 у 2014 р. на 10 тис. населення.

Виявлено, що упорядкування ліжкового фронду цілодобових стаціонарів здійснювалось переважно за рахунок закладів вторинної медичної допомоги. Найбільш активно відбувалось зменшення чисельності дільничних лікарень - 3668 од. до 104 од. (у6,4 разу), міськихлікареньдлядорослих-з 551од. до 390 од. (на 41,3\%), районних лікарень з 142 од. до 101 од. (на 40,6\%), міських лікарень для дітей - з 99 од. до 88 од. (на 12,5\%) (табл. 2).

Відповідним чином скорочувались ліжка: у дільничних лікарнях - у 5,6 разу, у міських лікарнях для дорослих - на 16,3\%, у міських лікарнях для дітей - на 12,8\%. Відбувалась реорганізація ліжкових потужностей та інших стаціонарних закладів вторинної медичної допомоги.

Акцент на впорядкування стаціонарної медичної допомоги вторинного рівня зумовлювався науково обґрунтованими висновками про існуючі недоліки в її організації [6;11]:

- надлишкова кількість лікарняних закладів і госпітальних ліжок при їх надмірній спеціалізації;

- висока питома вага госпіталізованих до спеціалізованих стаціонарів при необґрунтовано тривалих термінах перебування у стаціонарі;
- відсутність диореренціації ліжкового фронду залежно від інтенсивності лікування при низькій якості медичної допомоги;

- невиправдано високий рівень споживання населенням послуг вторинної медичної допомоги і, насамперед, тієї їх частини, яка надається у цілодобових стаціонарах;

- прямий доступ без направлення з рівня первинної медико-санітарної допомоги (ПМСД) до вторинної медичної допомоги.

Зазначені висновки науковців підтверджені, зокрема, аналізом статистичних даних про використання ліжкового фонду лікарняних закладів системи МО3 України за 2005-2014 роки (табл. 3).

Відбулось помірне зменшення середнього числа днів зайнятості (роботи) ліжка з 334,9 до 322,8 за 2005-2014 рр. Однак загалом найменший рівень показника вказує на використання ліжка в обсязі 94,7\% від можливого, що відповідає рекомендаціям ВООЗ стосовно раціонального використання ліжкового фондузаданоюхарактеристикою. Разом з тим показник тривалості перебування хворого на ліжку, який впливає на зайнятість ліжка, незважаючи на зменшення 3 13,5 до 11,6, залишається значно вищим за середньоєвропейський показник 9,2 дня. Показник обігу ліжка зростав за період, охоплений аналізом, відповідно до зменшення тривалості лікування 3 24,8 до 27,86 за рік.

Незважаючи на скорочення лікарняної мережі і розвиток альтернативних фрорм стаціонарної медичної допомоги, зберігається високий рівень 
ОРГАНІЗАЦІЯ МЕДИЧНОЇ ДОПОМОГИ

Таблиця 2. Динаміка змін мережі та ліжкового фонду основних типів лікарняних закладів (2005-2014 рр.)

\begin{tabular}{|c|c|c|c|c|c|c|}
\hline \multirow{2}{*}{ Показник } & \multicolumn{6}{|c|}{ Рік } \\
\hline & 2005 & 2007 & 2010 & 2011 & 2013 & 2014 \\
\hline \multicolumn{7}{|c|}{ Мережа лікарняних закладів } \\
\hline Лікарняні заклади, усього & 2636 & 2574 & 2442 & 2473 & 1819 & 1504 \\
\hline у т.ч. обласні лікарні & 25 & 25 & 27 & 27 & 27 & 24 \\
\hline обласні дитячі лікарні & 29 & 29 & 29 & 29 & 29 & 27 \\
\hline міські лікарні & 551 & 547 & 516 & 516 & 390 & 281 \\
\hline спеціалізовані лікарні & 112 & 119 & 126 & 126 & 122 & 111 \\
\hline дитячі міські лікарні & 99 & 97 & 94 & 94 & 88 & 59 \\
\hline центральні районні лікарні & 480 & 474 & 471 & 471 & 471 & 446 \\
\hline дільничні лікарні & 668 & 609 & 521 & 521 & 104 & 64 \\
\hline психіатричні, наркологічні & 92 & 92 & 90 & & 89 & 66 \\
\hline пологові будинки & 89 & 89 & 87 & 87 & 88 & 74 \\
\hline диспансери & 283 & 369 & 266 & & 232 & 192 \\
\hline районні лікарні & & 142 & & 140 & 101 & 91 \\
\hline \multicolumn{7}{|c|}{ Ліжковий фронд лікарняних закладів } \\
\hline Кількість ліжок, усього & 407464 & 404212 & 394374 & 377291 & 364241 & 307246 \\
\hline у т.ч. в обласних лікарнях & 20862 & 20789 & 21121 & 20860 & 20873 & 17380 \\
\hline обласних дитячих лікарнях & & & & 11442 & & \\
\hline міських лікарнях & 107703 & 106961 & 102859 & 96628 & 92603 & 69503 \\
\hline спеціалізованих лікарнях & 16264 & 116071 & 17517 & 17517 & 16666 & 14501 \\
\hline дитячих міських лікарнях & 13923 & 10143 & 13259 & 13259 & 12345 & 9285 \\
\hline центральних районних & 104009 & 100668 & 96877 & 94753 & 93555 & 88257 \\
\hline дільничних лікарнях & 10486 & 9545 & 8131 & 5278 & 1882 & 1015 \\
\hline психіатричних, наркологічних & 43058 & 49654 & 41054 & & 38294 & 31559 \\
\hline пологових будинках & 13276 & 14035 & 13116 & 13116 & 12756 & 10885 \\
\hline диспансерах & 41579 & 43279 & 39768 & & 36597 & 29453 \\
\hline районних лікарнях & & 11009 & 11534 & 10474 & & \\
\hline
\end{tabular}

Примітка: за даними Центру медичної статистики МОЗ України.

Таблиця 3. Основні показники діяльності та використання ліжкового фонду лікарняних закладів системи МОЗ України (2005-2014 рр.)*

\begin{tabular}{|c|c|c|c|c|c|}
\hline \multirow{2}{*}{ Показник } & \multicolumn{5}{|c|}{ Pik } \\
\hline & 2005 & 2006 & 2007 & 2008 & 2009 \\
\hline Госпіталізація на 100 жителів, усього & 21,6 & 21,9 & 22,55 & 22,55 & 22,36 \\
\hline у т.ч. міських жителів & & 22,2 & 22,63 & 22,65 & 22,34 \\
\hline сільських жителів & & 21,3 & 22,37 & 22,34 & 22,41 \\
\hline Середнє число днів зайнятості ліжка & 334,9 & 333,7 & 333,94 & 330,6 & 326,62 \\
\hline Середнє перебування хворого на ліжку & 13,5 & 13,28 & 12,92 & 12,79 & 12,71 \\
\hline Обіг ліжка & 24,8 & 25,13 & 25,84 & 25,84 & 25,70 \\
\hline \multirow{2}{*}{ Показник } & \multicolumn{5}{|c|}{ Pik } \\
\hline & 2010 & 2011 & 2012 & 2013 & 2014 \\
\hline $\begin{array}{l}\text { Госпіталізація на } 100 \text { жителів, усього } \\
\text { у т.ч. міських жителів } \\
\text { сільських жителів }\end{array}$ & $\begin{array}{c}22,88 \\
22,87 \\
22,9\end{array}$ & $\begin{array}{l}22,61 \\
22,56 \\
22,71\end{array}$ & $\begin{array}{l}22,4 \\
22,3 \\
22,4\end{array}$ & $\begin{array}{l}22,4 \\
22,3 \\
22,6\end{array}$ & 20,0 \\
\hline Середнє число днів зайнятості ліжка & 329,4 & 327,94 & 330,1 & 328,6 & 322,8 \\
\hline Середнє перебування хворого на ліжку & 12,45 & 12,24 & 12,1 & 11,9 & 11,6 \\
\hline Обіг ліжка & 26,46 & 26,80 & 27,38 & 27,74 & 27,86 \\
\hline
\end{tabular}

Примітка: за даними Центру медичної статистики МОЗ України.

госпіталізації у цілодобові стаціонари, який зріс 3 21,6 у 2005 р. до 22,4 у 2013 р. на кожні 100 жителів, зокрема міського населення - 322,2 у 2006 р. до 22,3 у 2014 р., сільського - 3 21,3 до 22,6 відповідно.

За рівнями госпіталізації перші рангові місця у 2005-2014 рр. стабільно належали хворим з ускладненнями вагітності і пологів (відповідно
7,9-8,05), хворобами системи кровообігу (4,0$4,27)$, органів травлення $(2,1-1,79)$ і органів дихання $(2,0-1,68)$ (табл. 4).

Відбулося зростання рівнів госпіталізації хворих на новоутворення $(1,3-1,45)$, хвороби ендокринної системи $(0,5-0,52)$, кістково-м'язової системи та сполучної тканини $(1,2-1,29)$, нервової системи $(0,8-0,83)$, ока $(0,6-0,61)$. Зменшилось число 
Таблиця 4. Динаміка рівнів госпіталізації за класами хвороб у 2005-2014 рр. (на 100 осіб)*

\begin{tabular}{|c|c|c|c|c|c|}
\hline \multirow{2}{*}{ Клас хвороб } & \multicolumn{5}{|c|}{ Роки / рівні госпіталізації на 100 осіб } \\
\hline & 2005 & 2006 & 2007 & 2008 & 2009 \\
\hline Усього (А00-T98) & 21,1 & & & 22,35 & 21,86 \\
\hline у тому числі: Деякі інсрекційні та паразитарні хвороби (А00-В99) & 0,6 & 0,64 & 0,60 & 0,60 & 0,57 \\
\hline Новоутворення (C00-D48) & 1,3 & 1,31 & 1,35 & 1,47 & 1,47 \\
\hline $\begin{array}{l}\text { Хвороби крові, кровотворних органів і окремі порушення із залучен- } \\
\text { ням імунного механізму (D50-D89) }\end{array}$ & 0,1 & 0,06 & 0,06 & 0,06 & 0,06 \\
\hline $\begin{array}{l}\text { Хвороби ендокринної системи, розлади харчування та порушення } \\
\text { обміну речовин (ЕОО-Е90) }\end{array}$ & 0,5 & 0,47 & 0,49 & 0,53 & 0,52 \\
\hline Розлади психіки та поведінки (F00-F99) & 1,0 & 1,02 & 1,08 & 1,14 & 1,04 \\
\hline Хвороби нервової системи (G00-G99) & 0,8 & 0,78 & 0,80 & 0,84 & 0,82 \\
\hline Хвороби ока та його придаткового апарату (H00-H59) & 0,6 & 0,59 & 0,60 & 0,65 & 0,60 \\
\hline Хвороби вуха та соскоподібного відростка (Н60-Н95) & 0,2 & 0,15 & 0,15 & 0,16 & 0,16 \\
\hline Хвороби системи кровообігу (100-199) & 4,0 & 4,1 & 4,2 & 4,51 & 4,46 \\
\hline Хвороби органів дихання (J00-J99) & 2,0 & 1,84 & 1,91 & 1,93 & 2,04 \\
\hline Хвороби органів травлення (К00-К93) & 2,1 & 2,03 & 2,07 & 2,15 & 2,07 \\
\hline Хвороби шкіри та підшкірної клітковини (L00-L99) & 0,6 & 0,54 & 0,56 & 0,58 & 0,56 \\
\hline Хвороби кістково-м'язової системи та сполучної тканини (М00-М99) & 1,2 & 1,23 & 1,25 & 1,32 & 1,30 \\
\hline Хвороби сечостатевої системи (N00-N99) & 1,8 & 1,76 & 1,79 & 1,82 & 1,77 \\
\hline крім того: усклад. вагітності, пологів та післяпологового періоду 630-676 & 7,9 & 2,53 & 2,57 & 2,81 & 2,72 \\
\hline Окремі стани, що виникли в перинатальному періоді (Р00-Р96) & & & & 0.0 & 0.0 \\
\hline Природжені вади розвитку, деформації і хромосомні аномалії (Q00-Q99) & 0,1 & 0,06 & 0,06 & 0,06 & 0,06 \\
\hline $\begin{array}{l}\text { Симптоми, ознаки та відхилення від норми, що виявлені при лабораторних } \\
\text { та клінічних дослідженнях, не класифіковані в інших рубриках (R00-R99) }\end{array}$ & 0,02 & 0,02 & 0,02 & 0,02 & 0,02 \\
\hline Травми, отруєння та деякі інші наслідки дії зовнішніх чинників (S00-T98) & 1,7 & 1,68 & 1,67 & 1,72 & 1,61 \\
\hline \multirow{2}{*}{ Клас хвороб } & \multicolumn{5}{|c|}{ Рік } \\
\hline & 2010 & 2011 & 2012 & 2013 & 2014 \\
\hline Усього (А00-Т98) & 22,28 & 22,06 & 21,89 & 21,92 & 19,58 \\
\hline у тому числі: Деякі інфрекційні та & 0,57 & 0,55 & 0,55 & 0,53 & 0,46 \\
\hline Новоутворення (C00-D48) & 1,52 & 1,59 & 1,65 & 1,69 & 1,45 \\
\hline $\begin{array}{l}\text { Хвороби крові, кровотворних органів і окремі порушення із залучен- } \\
\text { ням імунного механізму (D50-D89) }\end{array}$ & 0,06 & 0,06 & 0,07 & 0,07 & 0,06 \\
\hline $\begin{array}{l}\text { Хвороби ендокринної системи, розлади харчування та порушення } \\
\text { обміну речовин (ЕОО-Е90) }\end{array}$ & 0,54 & 0,55 & 0,56 & 0,57 & 0,52 \\
\hline Розлади психіки та поведінки (F00-F99) & 1,02 & 1,02 & 1,02 & 1,00 & 0,85 \\
\hline Хвороби нервової системи (G00-G99) & 0,85 & 0,84 & 0,85 & 0,83 & 0,79 \\
\hline Хвороби ока та його придаткового апарату (H00-H59) & 0,63 & 0,62 & 0,62 & 0,61 & 0,53 \\
\hline Хвороби вуха та соскоподібного відростка (Н60-Н95) & 0,16 & 0,15 & 0,15 & 0,14 & 0,12 \\
\hline Хвороби системи кровообігу (100-199) & 4,8 & 4,59 & 4,58 & 4,66 & 4,27 \\
\hline Хвороби органів дихання (J00-J99) & 2,19 & 2,07 & 1,86 & 1,93 & 1,68 \\
\hline Хвороби органів травлення (К00-К93) & 2,06 & 2,01 & 2,00 & 1,99 & 1,79 \\
\hline Хвороби шкіри та підшкірної клітковини (L00-L99) & 0,57 & 0,54 & 0,51 & 0,50 & 0,45 \\
\hline Хвороби кістково-м'язової системи та сполучної тканини (М00-М99) & 1,32 & 1,31 & 1,30 & 1,29 & 1,18 \\
\hline Хвороби сечостатевої системи (NO0-N99) & 1,84 & 1,81 & 1,80 & 1,78 & 1,53 \\
\hline крім того: усклад. вагітності, пологів та післяпологового періоду 630-676 & 2,66 & 2,68 & 8,87 & 8,90 & 8,05 \\
\hline Окремі стани, що виникли в перинатальному періоді (Р00-P96) & 0,0 & 0,0 & & & \\
\hline Природжені вади розвитку, десрормації та хромосомні аномалії (Q00-Q99) & 0,07 & 0,08 & 0,08 & 0,07 & 0,07 \\
\hline $\begin{array}{l}\text { Симптоми, ознаки та відхилення від норми, що виявлені при лабораторних } \\
\text { та клінічних дослідженнях, не класифіковані в інших рубриках (R00-R99) }\end{array}$ & 0,02 & 0,02 & 0,02 & 0,02 & 0,02 \\
\hline Травми, отруєння та деякі інші наслідки дії зовнішніх чинників (S00-T98) & 1,63 & 1,57 & 1,58 & 1,57 & 1,40 \\
\hline
\end{tabular}

Примітка: за даними Центру медичної статистики МОЗ України.

госпіталізацій з приводу інфекційних хвороб (з 0,6 до 0,46), хвороб шкіри та підшкірної клітковини (3 0,6 до 0,45), природжених вад розвитку, десрормацій і хромосомних аномалій (з 1,0 до 0,07), травм, отруєнь та деяких інших наслідків дії зовнішніх чинників (з 1,7 до 1,4), хвороб вуха (з 0,2 до 0,12). Стабільним залишався рівень госпіталізації з приводу хвороб крові $(0,06)$, розладів психіки та поведінки $(1,0)$, сечостатевої системи $(1,8)$, симптомів, ознак та відхилень від норми, що виявлені при ла- 
бораторних та клінічних дослідженнях, не класифрікованих в інших рубриках $(0,2)$.

Простежені зміни у показниках діяльності закладів охорони здоров'я, що надають стаціонарну медичну допомогу, залежно від типу закладів (табл. 5). Так, обсяги госпіталізації до дільничних лікарень скоротились з 2,9\% до 0,3\%, до міських лікарень для дорослих - 3 30,8\% до 26,1\%. Водночас зросли обсяги госпіталізації до обласних лікарень як для дорослих (з 6,1\% до 6,9\%), так і для дітей (з 3,5\% до 4,1\%), а також найбільше до центральних районних лікарень (з 30,8\% до 34,2\%) і до спеціалізованих лікарень (з 2,9\% до 3,5\%). Середнє число днів роботи ліжка зросло в обласних лікарнях для дорослих (3 343,1 до 347,5) і для дітей (3 323,7 до $326,4)$, а зменшилось - у міських лікарнях (3 339,84 до 331,0), центральних районних лікарнях (3 333,76 до 320,8), дільничних (3 341,2 до 329,9) та районних (з 336,9 до 327,8) лікарнях.

Водночас найбільш раціонально використовуваним за результатами реформування слід вважати ліжковий фонд обласних дитячих та центральних районних лікарень: при середньому числі днів роботи ліжка відповідно 96,0\% і 96,4\% від можливого у 2014 р. в них досягнуто майже європейських показників середньої тривалості перебування хворих на ліжку: відповідно 9,6 (10,6 у 2006 р.) та 9,7 (11,2 у 2005 р.).

У закладахохорони здоров'яіншихтипів тривалість перебування хворих у стаціонарі у 2014 р. значно перевищувала середньоєвропейський показник, незважаючи на позитивну динаміку його змін: у обласних лікарнях для дорослих - 10,2 (11,6 у 2005 р.), у міських лікарнях для дорослих - 10,3 (11,8 у 2005 р.),

Таблиця 5. Обсяги госпіталізації у лікарняні заклади (у відсотках) залежно від типу закладу охорони здоров'я*

\begin{tabular}{|l|c|c|c|c|c|c|}
\hline \multirow{2}{*}{ Показник } & \multicolumn{3}{c|}{ Рік } \\
\cline { 2 - 7 } & 2005 & 2007 & 2010 & 2012 & 2013 & 2014 \\
\hline Кількість госпіталізованих, усього & 100,0 & 100,0 & 100,0 & 100,0 & 100,0 & 100,0 \\
\hline у т.ч. в обласні лікарні & 6,1 & & 6,4 & 6,8 & 6,8 & 6,9 \\
\hline дитячі обласні & & & 3,5 & 3,8 & 3,9 & 4,1 \\
\hline міські & 30,8 & & 30,2 & 29,7 & 29,4 & 26,1 \\
\hline спеціалізовані & 2,9 & & 3,2 & 3,3 & 3,3 & 3,5 \\
\hline дитячі міські & 3,9 & & 4,2 & 4,1 & 4,2 & 3,7 \\
\hline центральні районні & 30,8 & & 29,9 & 30,4 & 30,9 & 34,2 \\
\hline дільничні & 2,9 & & 2,3 & 1,3 & 0,7 & 0,3 \\
\hline психіатричні та наркологічні & 2,9 & & 2,6 & 2,7 & 2,7 & 2,6 \\
\hline пологові будинки & 4,4 & & 4,3 & 4,6 & 4.5 & 4,5 \\
\hline стаціонари диспансерів & 5,8 & & 5,8 & 5,9 & 6,0 & 5,8 \\
\hline районні & & & 3,3 & 3,0 & 3,0 & 3,2 \\
\hline
\end{tabular}

Примітка: за даними Центру медичної статистики МОЗ України.

у дільничних лікарнях - 11,5 (11,8 у 2005 р.), у районних лікарнях - 10,2 (11,4 у 2008 р.).

\section{Висновки}

В Україні ще зберігається надмірна кількість ліжкового фронду та надмірне споживання населенням стаціонарної медичної допомоги, що підтримує низьку ефрективність використання ресурсів галузі.

Вимагають інтенсивнішого розвитку альтернативні фрорми стаціонарної медичної допомоги.

Отримані результати підтверджують збереження актуальності проблеми використання ліжково- го фронду в Україні, незавершеність процесу скорочення лікарняних ліжок і приведення їх числа у відповідність до потреб населення.

Існують резерви підвищення ефективності використання потенціалу лікарняних закладів, які мають торкатися обсягу їх ліжкового фонду, дотримання показань до перебування хворих та подальшого розвитку стаціонарозамінних фрорм медичної допомоги, чому необхідно присвятити подальші наукові дослідження.

\section{Список літератури}

1. Мокрицька А. Б. Структурні диспропорції та проблеми фрінансування вітчизняної охорони здоров'я / А. Б. Мокрицька // Матеріали наукової конференції профресорсько-викладацького складу [«Методологічні проблеми фрінансової теорії та практики в умовах світової економічної кризи»], (Тернопіль, 15 квітня 2009 року). - Тернопіль : Тернопільський національний економічний університет, 2009. - С. 97-103.

2. Національна стратегія побудови нової системи охорони здоров'я в Україні на період 2015-2025 [Електронний ресурс]. - Київ, листопад 2014 року. - Режим доступу : http://uoz-zak.gov.ua/uploads/doc/1/4/9/149.pdf.

3. Про затвердження нормативів потреб у стаціонарній медичній допомозі в розрахунку на 10 тисяч населення : Постанова Кабінету Міністрів України від 28.06.1997 р. № 640 [Електронний ресурс]. - Режим доступу : http:// zakon5.rada.gov.ua/laws/show/640-97-\%D0\%BF.

4. Слабкий В. Г. Сучасний стан організації стаціонарної медичної допомоги населенню України та інших країн / В. Г. Слабкий, Н.П.Кризина, Г. Я. Пархоменко // Сучасні медичні технології. - 2013. - № 2. - С. $150-151$. 
5. Характеристика мережі закладів охорони здоров'я, забезпеченості населення лікарняними ліжками та основні показники їх використання [Електронний ресурс] / Слабкий Г. О., Пархоменко Г. Я., Кондратюк Н. Ю., Торжевська О. М. // Укр. мед. часоп. - 2014. - № 5 (103), IX/X. - Режим доступу : http://www.umj.com.ua.

6. Щорічна доповідь про результати діяльності системи охорони здоров'я України. 2013 рік / Український інститут стратегічних досліджень МОЗ України. - Київ, 2014. - 438 с.

7. Щорічна доповідь про стан здоров'я населення України та санітарно-епідеміологічну ситуацію. 2005 рік. К., 2006. -278 c.

8. Щорічна доповідь про стан здоров'я населення України та санітарно-епідеміологічну ситуацію. 2006 рік. К., 2007. - 398 c.

9. Щорічна доповідь про стан здоров'я населення України та санітарно-епідеміологічну ситуацію. 2007 рік. К., 2008. -262 c.

10. Щорічна доповідь про стан здоров'я населення України та санітарно-епідемічну ситуацію. 2008 рік. - К., 2009.

11. Щорічна доповідь про стан здоров'я населення України та санітарно-епідемічну ситуацію. 2010 рік : [монографрія] / за ред. О. В. Аніщенко. - К., 2011. - С. 295-313.

\section{ДОСТИЖЕНИЯ И ПЕРСПЕКТИВЫ РАЗВИТИЯ СТАЦИОНАРНОЙ МЕДИЦИНСКОЙ ПОМОЩИ В УКРАИНЕ \\ В.И. Бугро, В.В. Горачук}

Национальная медицинская академия последипломного образования имени П.Л. Шупика, г. Киев, Украина

Цель: анализ показателей деятельности стационаров Украины за 2005-2014 гг. с определением перспектив дальнейших направлений реформирования стационарной медицинской помощи.

Материалы и методы. Использованы отечественные научные и статистически-справочные материалы по теме: применялись следующие методы: библиосемантический, медико-статистический, системного подхода и системного анализа.

Результаты. Несмотря на упорядочение сети больниц и развитие учреждений семейной медицины, остаются высокими показатели обеспеченности населения стационарными койками (71,9 на 10 тыс. нас., в странах EC - 55,0), продолжительности пребывания больного на койке $(11,6$ дней, среднеевропейский показатель - 9,2 дня) при сокращении среднего числа дней работы койки в городских (с 339,84 до 331,0), центральных районных (с 333,76 до 320,8), участковых (с 341,2 до 329,9), районных больницах (с 336,9 до 327,8) и коечного фонда дневных стационаров (с 4659 ед. до 1924 ед.).

Выводы. Существуют резервы улучшения использования коечного фронда относительно объема, сроков пребывания на койке и дальнейшего развития стационарозаменяющих форм медицинской помощи.

КЛЮЧЕВЫЕ СЛОВА: коечный фонд, стационарная медицинская помощь, рациональное использование ресурсов.

\section{ACHIEVEMENTS AND PROSPECTS INPATIENT CARE IN UKRAINE}

V.I. Bugro, V.V. Horachuk

National Medical Academy of Post-graduate Education named P.L. Shupik, Kyiv, Ukraine

Purpose. The aim of the study is systematic analysis of performance of the hospitals of Ukraine in 2005-2014 and determining of prospects of further directions of reforming the hospital care.

Materials and methods. We used methods of system approach and system analysis, health statistics. Our study found that, despite setting hospital network in order and developing institutions of general practice/family medicine, still high are availability of inpatient beds to the population (71.9 per 10,000 people, while in the EU 55.0 ), length of hospital stay (11.6 days, the European average - 9.2 days), while there is a reduction of average number of days of bed occupancy in city hospitals (from 339.84 to 331.0), central district hospitals (from 333.76 to 320.8), local hospitals (from 341.2 to 329.9), district hospitals (from 336.9 to 327.8), as well as of the number of beds in day hospitals (from 4659 to 1924). Results of the analysis allow us to draw conclusions about the reserves of volume-related improvement of bed use, compliance with indications for patient stay at day-night beds and further development of day hospitals.

KEY WORDS: hospital beds, inpatient care, rational use of resources.

Рукопис надійшов до редакції 10.11.2015 р.

Відомості про авторів:

Бугро Валерій Іванович - к.мед.н., доц. кафр. управління охороною здоров'я Національної медичної академії післядипломної освіти імені П. Л. Шупика, заслужений працівник охорони здоров'я України; тел. служб.: +38 (044) 2054990.

Горачук Вікторія Валентинівна - к.мед.н., доц. каф. управління охороною здоров'я Національної медичної академії післядипломної освіти імені П. Л. Шупика; тел. служб.: +38(044) 205-49-90. 